\title{
Problem Posing Sebagai Kemampuan Matematis
}

\author{
Problem Posing as Mathematical SKILl
}

\author{
Ekasatya Aldila Afriansyah \\ Pendidikan Matematika, STKIP Garut \\ e_satya@yahoo.com
}

\begin{abstract}
Abstrak
Perlunya kemampuan dalam membuat permasalahan/persoalan matematis sangat diperlukan oleh seorang guru. Hal tersebut berguna agar guru tidak hanya memberikan soal yang ada di buku saja. Guru dituntut kreatif; guru perlu memiliki kemampuan dalam membuat soal yang dibutuhkan oleh siswanya. Selama ini, kemampuan yang terus disoroti adalah kemampuan dalam menyelesaikan berbagai tipe soal dilihat dari daya pikir siswanya. Untuk kali ini, kita coba lihat dari sudut pandang perlunya kemampuan seorang guru untuk memiliki kemampuan pengajuan permasalahan matematis (mathematical problem posing) ini. Seiring dengan meningkatnya kemampuan membuat soal yang baik tentunya dapat meningkatkan kualitas pembelajaran di kelas. Kemampuan mathematical problem posing ini masih menjadi kendala bagi beberapa mahasiswa calon guru matematika, padahal kemampuan ini sangat diperlukan bagi mereka yang akan menjadi seorang guru yang baik. Oleh karena itu, pada kesempatan ini, kita akan coba paparkan problem posing sebagai suatu kemampuan matematis yang diperlukan oleh seseorang, terutama calon guru.

Kata Kunci: kemampuan pengajuan permasalahan matematis, kemampuan matematis, calon guru matematika.
\end{abstract}

\begin{abstract}
The need for the skill to create mathematical problems/issues needed by a teacher. It is useful for teachers to provide problems that exist in books only. Teachers need to be creative; teachers need to have the skill to create questions that needed by their students. During this time, a skill that continues to be highlighted is the ability to resolve various types of problems seen from the intellect students. For this time, we look from the perspective of the need for the skill of a teacher to have the skill of mathematical problem posings. Along with the increased mathematical problem posing skill can certainly improve the quality of learning in the classroom. Mathematical problem posing skill is still an obstacle for some mathematics prospective teachers, but this skill is very necessary for those who would become a good teacher. Therefore, on this occasion, we will try to present problem posing as a mathematical skill needed by someone, especially prospective teachers.
\end{abstract}

Keyword: mathematical problem posing, mathematical skill, prospective teacher.

\section{Pendahuluan}

Perlu kita sadari bahwa tidak semua kemampuan yang perlu dimiliki seseorang adalah berupa menyelesaikan suatu permasalahan. Hal ini dikarenakan perlunya permasalahan ada terlebih dahulu sebelum kita mencoba untuk menyelesaikannya. Oleh karena itu, 
seseorang perlu memiliki kemampuan dalam menyelesaikan suatu permasalahan; begitu pula sebaliknya, perlunya seseorang untuk memiliki kemampuan membuat permasalahan.

Kemampuan dalam membuat permasalahan perlu dimiliki oleh seorang guru. Guru dituntut untuk kreatif dalam memberikan suatu permasalahan (soal) yang akan dikerjakan oleh siswanya. Dalam bidang matematika, kita dapat katakan sebagai kemampuan dalam mengajukan permasalahan matematis (mathematical problem posing).

Ellerton dan Clarkson (1996) yang mengatakan pentingnya memiliki kemampuan mathematical problem posing terlukis dalam pernyataan bahwa pengembangan kemampuan matematis membutuhkan kemampuan berimaginasi kreatif matematis yang antara lain berkembang ketika memunculkan pertanyaan baru, menciptakan peluang baru, dan memandang pertanyaan lama dari sudut pandang baru. Kemampuan dalam memunculkan dan menciptakan permasalahan matematika yang baru ini tidak kalah pentingnya dalam menyelesaikan masalah matematika, sehingga pengajuan masalah matematika ini dapat dikatakan pula adalah bagian penting dalam kegiatan pembelajaran.

Weiss dan Moore-Russo (2012) mengatakan dalam penelitiannya bahwa pentingnya peran problem posing dalam pembelajaran matematika telah diketahui sejak lama. Problem posing ini telah digunakan sebagai alat ukur pemahaman konseptual dan juga sebagai alat pedagogik (Choe dan Mann, 2012). Tidak terlepasnya peran problem posing sebagai alat pedagogik, membuat problem posing ini menjadi sangat penting untuk dipahami oleh para guru dan siswa tentunya.

Crespo (2003) mengemukakan pengalaman guru-guru dalam menempuh studinya selama kurang lebih 16 tahun lamanya, para guru tersebut cenderung terbiasa menyelesaikan dan menjawab permasalahan yang dosennya berikan melalui buku teks yang digunakan selama perkuliahan. Dikarenakan hal ini, para guru tersebut telah terbiasa melakukan pembelajaran dengan situasi tanpa posing dari semenjak studi. Sehingga berakibat bahwa tidak mudah bagi para guru khususnya untuk menerapkan posing di kelasnya. Untuk itu, problem posing merupakan salah satu tantangan dalam proses pembelajaran matematika di kelas, baik itu untuk siswa maupun gurunya sendiri.

Problem posing merupakan permasalahan yang diformulasi oleh seorang siswa seiring dari pengaruh problem solving. Di dalam memahami problem solving tersebut tidak dipertanyakan kevaliditasan solusi dari permasalahannya akan tetapi tujuannya adalah menghasilkan permasalahan baru (Choe dan Mann, 2012). Permasalahan yang dibentuk melalui problem posing ini dapat berkembang level kesulitannya dari waktu ke waktu. Akan tetapi, hal tersebut tergantung pada peran dari seorang guru untuk dapat memberikan pengaruh yang 
positif, yaitu problem posing dapat membangun pemahaman siswa bukanlah sebaliknya problem posing menjadi hambatan dalam proses pembelajaran.

Dalam proses pembelajaran, problem posing ini dapat dimunculkan dalam segala tahapan kegiatan pembelajaran sebagai bagian dari proses pembelajaran. Tahapan dari problem posing ini berkaitan dengan tahapan dari problem solving yang dikemukakan oleh Polya (1985), dikarenakan Polya memberikan arahan dari tiap tahapan problem solving melalui pertanyaan, tugas, ataupun problem posing sebagai berikut: problem posing sebelum, selama, dan setelah problem solving.

Problem posing sebelum problem solving, adalah masalah yang digeneralisasi dari situasi, keadaan, ataupun kondisi tertentu. Situasi yang dapat mendorong munculnya masalah tersebut dapat berupa gambar, cerita, grafik, pertanyaan, dan sebagainya. Problem posing selama problem solving, adalah menyederhanakan masalah ke dalam bentuk sub-masalah dalam rangka strategi problem solving. Dalam hal ini, masalah yang umum dan complicated diuraikan menjadi masalah-masalah khusus yang lebih mudah untuk diselesaikan. Problem posing setelah problem solving, adalah mengembangkan masalah yang baru dengan cara memodifikasi masalah lama dengan cara tertentu. Cara yang dipilih dalam memodifikasi soal tersebut dapat dengan mengurangi keterangan dari situasi masalah lama, menambah keterangan situasi baru, merubah total situasinya dan hanya mempertahankan topik intinya saja, dan lain-lain.

Berkaitan dengan tahapan problem posing tersebut, Silver (1994) menyatakan bahwa problem posing merupakan sesuatu yang berguna tidak hanya dalam proses pembelajaran matematika, tetapi juga dapat membantu menciptakan situasi pembelajaran dimana siswa menjadi lebih termotivasi untuk belajar. Dalam penelitian Silver ini, problem posing tidak hanya dilihat dari strategi pembelajarannya ataupun kemampuan matematisnya saja, akan tetapi dapat juga dilihat sebagai 'scaffold' dari model pembelajaran yang digunakan.

Bentuk ataupun cara yang diajukan oleh seorang guru di kelas dalam melakukan problem posing tersebut berperan penting pada keadaan kognitif dan afektif seorang siswa. Karena itu, pembuatan dan pemilihan permasalahan matematika yang baik sangat digarisbawahi dalam Standar Profesional NCTM sebagai salah satu keputusan pedagogik yang paling penting untuk dilakukan oleh seorang guru. Permasalahan yang diambil seharusnya dipilih dikarenakan permasalahan tersebut memiliki potensi untuk mengangkat intelektual siswa, dapat pula diselesaikan dengan lebih dari satu cara yang menarik, dan dapat menstimulasi siswa untuk dapat membuat koneksi dan mengembangkan paradigma yang koheren untuk ide-ide matematika (NCTM, 1991). 
Seiring dengan pernyataan NCTM sebelumnya tentang kriteria pemilihan masalah yang diambil dalam proses pembelajaran, masalah tersebut dapat ditinjau dari beberapa hal. Masalah ditinjau dari sifatnya, masalah dapat bersifat tertutup (closed problem) dan masalah yang bersifat terbuka (open problem). Masalah yang dikatakan bersifat tertutup ketika masalah tersebut memiliki satu cara penyelesaian dan satu solusi, sedangkan masalah yang bersifat terbuka memiliki lebih dari satu cara penyelesaian atau lebih dari satu solusi. Jika masalah ditinjau dari susunan komponennya, masalah dapat bersifat terstruktur (well structured) ataupun tidak terstruktur (ill structured). Masalah dikatakan terstruktur bila seluruh komponen yang diperlukan untuk menyelesaikan masalah tersebut telah tersedia, sedangkan masalah dikatakan tidak terstruktur bila masalah tersebut tidak dapat diselesaikan karena kurang informasi, komponen yang diperlukan untuk menyelesaikan masalahnya masih kurang.

Menurut Stoyanova dan Ellerton (dalam Bonotto, 2013) masalah problem posing (MPP) apabila ditinjau dari situasi atau kondisinya dibagi menjadi tiga golongan, yaitu:

a. Free (bebas). Situasi masalah problem posing yang bebas, adalah situasi yang terbuka dan tanpa batas; siswa dapat mengajukan masalah yang sukar ataupun mudah selama masalah tersebut tidak menyimpang dari matematika dan masih memiliki solusi. Situasi bebas ini memiliki arti memberikan kebebasan sepenuhnya kepada siswa untuk melakukan problem posing, sebab siswa tidak diberi keterangan/komponen yang harus digunakan.

b. Semi-structured (semi-terstruktur). Situasi masalah problem posing yang semi-terstruktur, adalah situasi yang masih terbuka tetapi memiliki sedikit batasan (diberikan beberapa keterangan/komponen yang dapat mengarahkan ke bentuk pengajuan masalah yang diajukan siswa). Dalam hal ini, siswa dalam mengajukan masalah perlu memperhatikan beberapa keterangan/komponen yang diberikan dan perlu menggunakan pengetahuan yang telah dipelajari sebelumnya. Dalam situasi ini, siswa diminta menyelidiki situasi tertentu dengan menggunakan pengetahuan dan konsep yang telah dimilikinya dan menghubungannya dengan pengalaman matematik mereka sebelumnya, setelah itu siswa perlu mengkaitkan situasi tersebut dengan konsep atau prinsip matematika dalam melakukan problem posing.

c. Structured (terstruktur). Situasi masalah problem posing yang terstruktur, adalah situasi yang tertutup dan terbatas; siswa dalam mengajukan masalah perlu memperhatikan semua keterangan/komponen yang ada dan mempergunakannya dalam 
mereformulasikan permasalahan baru. Problem posing yang dibentuk dengan mereformulasikan permasalahan baru dapat berupa mereformulasi masalah yang sudah terselesaikan dengan menambah atau mengurangi situasi, ataupun meragamkan dengan situasi dari masalah yang diberikan.

Pentingnya seorang siswa memiliki kemampuan problem posing ini tertuang dalam NCTM (2000) yang menganjurkan bahwa siswa harus dilatih dalam merumuskan masalah atau pertanyaan sesuai dengan situasi yang disajikan baik di dalam ataupun di luar matematika. Sejalan dengan pernyataan tersebut Einstein (Shriki, 2013) mempercayai bahwa "Mengajukan masalah adalah lebih esensial daripada menyelesaikan masalah dan mendapatkan solusi, mengajukan masalah ini berarti memunculkan masalah baru, kemungkinan baru, memandang masalah lama dari sudut pandang baru yang membutuhkan imaginasi kreatif dan menandai kemajuan nyata dalan sains".

Problem posing dipandang sebagai proses mengajukan masalah yang memicu berlangsungnya kegiatan matematik (da Ponte dan Henriques, 2013). Hal ini memungkinkan penerapan kemampuan problem posing dalam kegiatan pembelajaran sebagai salah satu bagian dalam mengembangkan kemampuan berpikir matematis atau pola pikir matematis siswa secara umum.
Beberapa aspek dari problem posing yang didiskusikan dalam dokumen NCTM (1991), sebagai berikut:
a. Banyaknya permasalahan yang diajukan di setiap lembar.
b. Tipe problem atau permasalahan (rutin/non rutin, satu jawaban/komputasional, banyak jawaban/banyak cara)

c. Bentuk problem atau permasalahan (tanpa memiliki konteks/memiliki konteks, tipe buku teks/tipe investigasi)

d. Tipe adaptasi (tertutup/terbuka terhadap jawaban, solusi, dan interprestasi)

e. Sumber problem atau permasalahan (buku teks, situasi kelas, pengembangan sendiri)

f. Diiringi pertanyaan dan 'scaffold' (membimbing, mencari tahu, memberikan tantangan)

g. Diiringi refleksi (fokus, lamanya proses, isi)

Beberapa tipe dan metode dalam problem posing dikemukakan oleh Choe dan Mann (2012), diantaranya:

a. Memahami situasi sebagai suatu masalah ketika situasi tersebut memuncak.

b. Mempertanyakan atau mempermasalahkan masalah yang sudah ada.

c. Memberikan tujuan yang lebih dari seharusnya/menantang.

Selain itu juga, Choe dan Mann (2012) mengemukakan beberapa faktor penting yang dapat berkontribusi terhadap 
problem posing, yaitu: (1) grounding, (2) affordances, (3) analogy, (4) seperti apa matematika formal yang dipergunakan, dan (5) bagaimana mengukur baiknya problem posing tersebut.

Sementara itu, Weiss (2009) mengidentifikasi lima "generative moves" dalam problem posing, diantaranya: (1) Penguatan/melemahkan hipotesis, Penguatan/melemahkan kesimpulan, (3) Membuat menjadi umum, (4) Membuat menjadi khusus, dan mempertimbangkan kebalikannya. Kelima langkah ini dapat digunakan untuk mendeskripsikan dan memunculkan keinginan tentang mana yang benar secara matematika, hal tersebut merupakan bagian penting dari berpikir matematika secara fleksibel. Kelima langkah ini pun dapat menghubungkan temuan-temuan siswa di dalam pembelajaran menjadi teori yang terpadu.

\section{KAJIAN TEORI}

Untuk melihat kualitas dari problem posing yang telah diajukan oleh siswa, dapat dianalisis lebih rinci berdasarkan dimensi kreatifnya. Akan tetapi, sebelum itu, diperlukan terlebih dahulu untuk dilakukan analisis kelayakan dari problem posing tersebut seperti yang dikemukakan oleh Silver dan Cai (1996), melalui struktur masalah yang termuat dalam gambar di bawah ini.

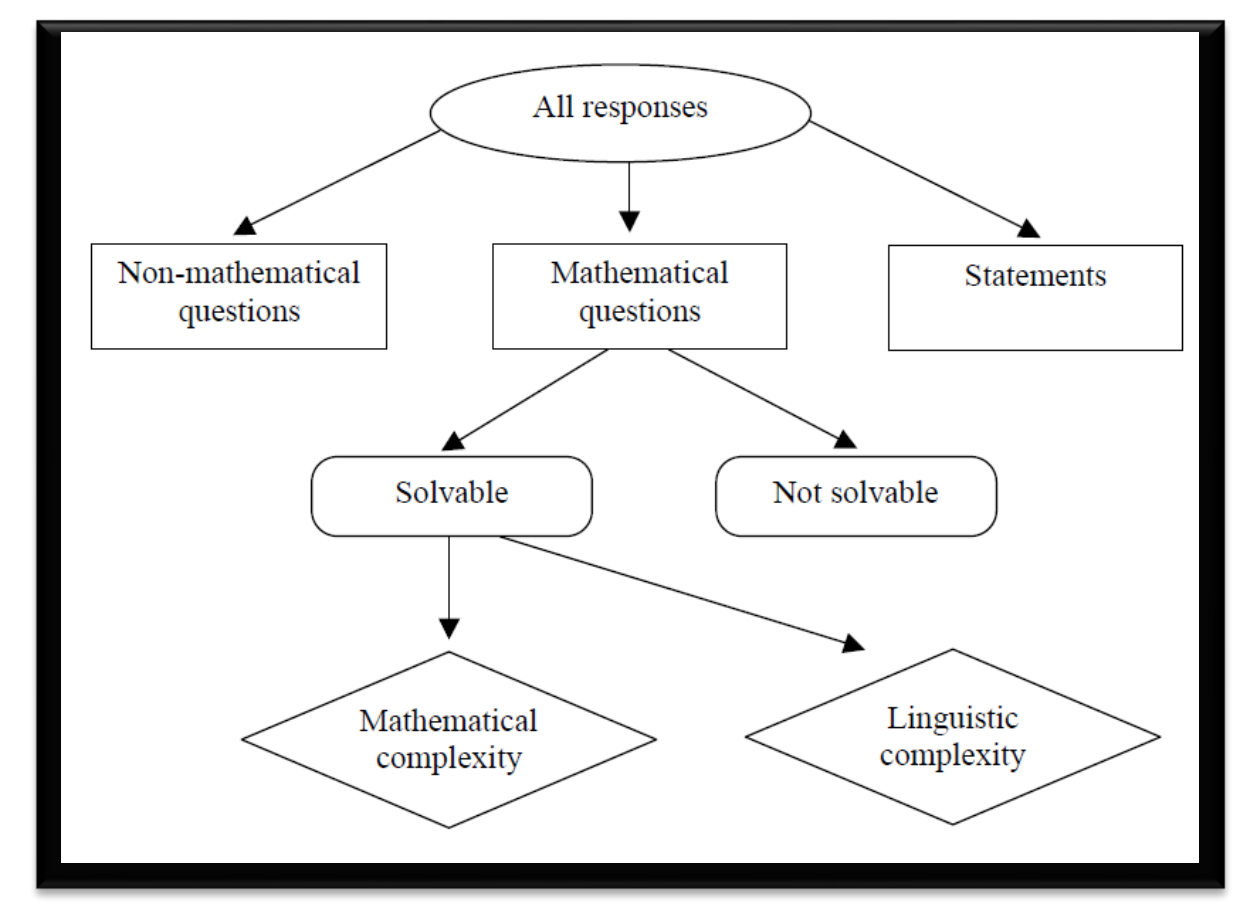

Gambar 1. Analisis kelayakan masalah problem posing.

Sejalan dengan apa yang dikatakan mathematical problem posing yang Silver dan Cai, Sumarmo (2014) diajukan oleh siswa dan atau yang menggambarkan analisis kualitas disajikan oleh guru. Analisis dilakukan 
didasarkan pada dimensi kreatifnya, berikut analisis terhadap kualitas bentuk masalah yang disajikan siswa/guru mealui struktur masalah yang termuat dalam mathematical problem posing pada gambar 2 berikut.

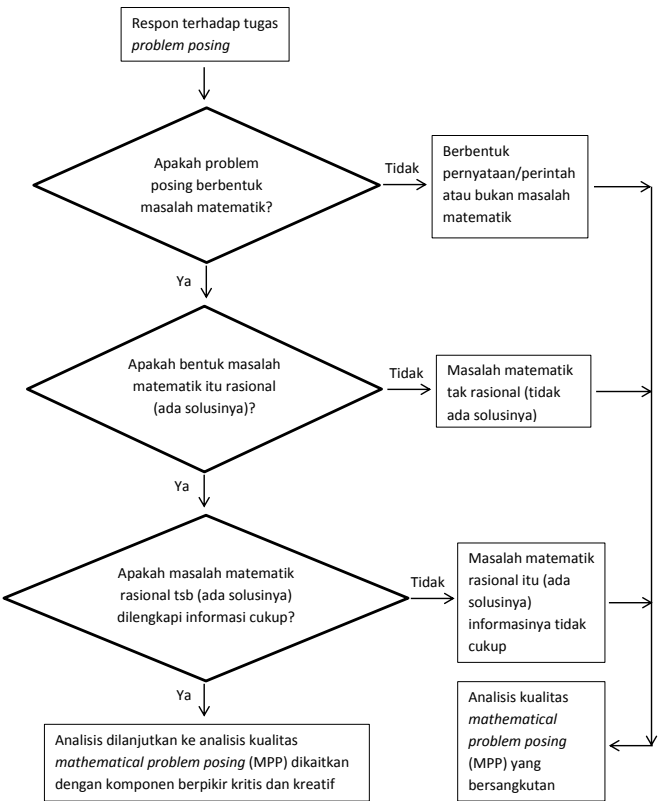

Gambar 2. Analisis terhadap kualitas bentuk masalah yang disajikan guru dan diajukan siswa menurut Sumarmo (2014)

Ellerton (dalam Sumarmo, 2014) menggambarkan kerangka kerja pembelajaran dengan proyek tugas menyusun mathematical problem posing yang dilukiskan pada gambar berikut.

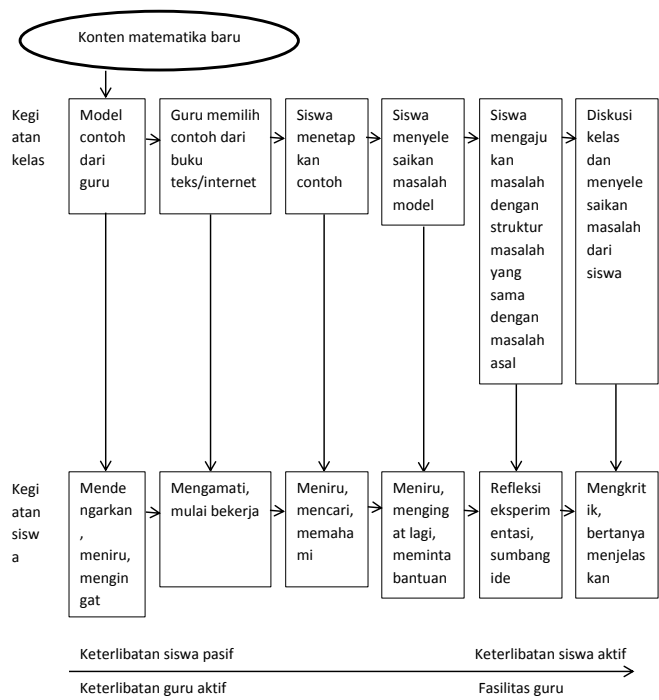

Gambar 3. Kerangka kerja menempatkan mathematical problem posing di kelas menurut Ellerton (dalam Sumarmo, 2014)

Selain kerangka kerja, Ellerton pun mengajukan sebuah model penilaian pendapat siswa terhadap tugas penyusunan mathematical problem posing. Berikut disajikan skala yang diajukan oleh Ellerton dalam bentuk skala Likert (Tabel 1).

Tabel 1.

Contoh skala pendapat siswa terhadap tugas menyusun mathematical problem posing menurut Ellerton (dalam Sumarmo, 2014)

Petunjuk: Bubuhkan tanda $\vee$ pada kolom yang sesuai dengan pendapat anda Keterangan: SS: Sangat Setuju; N:Netral; TS: Tidak Setuju; S: Setuju; STS: Sangat Tidak Setuju

\begin{tabular}{|c|c|c|c|c|c|c|}
\hline No. & Pernyataan & SS & $S$ & $\mathrm{~N}$ & TS & STS \\
\hline 1. & $\begin{array}{l}\text { Tugas menyusun masalah matematik lebih } \\
\text { menantang daripada tugas menyelesaikan } \\
\text { masalah }\end{array}$ & & & & & \\
\hline 2. & $\begin{array}{l}\text { Tugas menyusun masalah matematik } \\
\text { membantu saya memahami konsep } \\
\text { matematik yang sedang dipelajari }\end{array}$ & & & & & \\
\hline 3. & $\begin{array}{l}\text { Tugas menyusun masalah matematik } \\
\text { menghambat saya menyelesaikan masalah }\end{array}$ & & & & & \\
\hline
\end{tabular}




\begin{tabular}{|c|c|}
\hline & matematik yang sedang dihadapi \\
\hline 4. & $\begin{array}{l}\text { Tugas menyusun masalah matematik } \\
\text { mendorong pengembangan berpikir kritis } \\
\text { matematik }\end{array}$ \\
\hline 5. & $\begin{array}{l}\text { Tugas menyusun masalah matematik } \\
\text { melatih pengembangan berpikir kreatif } \\
\text { matematik }\end{array}$ \\
\hline 6. & $\begin{array}{l}\text { Ketika belajar, saya senang/suka menyusun } \\
\text { masalah matematik }\end{array}$ \\
\hline 7. & $\begin{array}{l}\text { Saya percaya dapat menyusun masalah } \\
\text { matematik dari data/situasi yang disajikan }\end{array}$ \\
\hline 8. & $\begin{array}{l}\text { Tugas menyusun masalah matematik } \\
\text { membuat saya cemas }\end{array}$ \\
\hline 9. & $\begin{array}{l}\text { Saya berharap mendapat kesempatan lebih } \\
\text { banyak menyusun masalah matematik } \\
\text { selama pelajaran matematik }\end{array}$ \\
\hline 10. & $\begin{array}{l}\text { Saya lebih memilih tugas menyelesaikan } \\
\text { masalah matematik daripada tugas } \\
\text { menyusun masalah matematik dari situasi } \\
\text { yang dihadapi }\end{array}$ \\
\hline 11. & $\begin{array}{l}\text { Tugas menyusun masalah matematik } \\
\text { menghamburkan waktu belajar }\end{array}$ \\
\hline 12. & $\begin{array}{l}\text { Tugas menyusun masalah matematik } \\
\text { melatih berpikir kreatif }\end{array}$ \\
\hline 13. & $\begin{array}{l}\text { Tugas menyusun masalah matematik } \\
\text { membantu saya menyelesaikan masalah } \\
\text { yang relevan }\end{array}$ \\
\hline 14. & $\begin{array}{l}\text { Tugas menyusun masalah matematik adalah } \\
\text { tugas guru saja }\end{array}$ \\
\hline
\end{tabular}

Catatan: Untuk pernyataan positif, respon SS bernilai 5; respon $\mathrm{S}$ bernilai 4; respon $\mathrm{N}$ bernilai 3; respon TS bernilai 2; respon STS bernilai 1

Untuk pernyataan negatif, respon SS bernilai 1; respon $\mathrm{S}$ bernilai 2; respon $\mathrm{N}$ bernilai 3; respon TS bernilai 4; respon STS bernilai 5

Tuliskan pendapat, kesan, atau komentar anda terhadap tugas menyusun masalah dalam pembelajaran matematik pada tempat tersedia dibawah ini.

Setelah itu, masalah mathematical problem posing yang telah memiliki keterangan/komponen yang cukup, memiliki solusi, dan memiliki kesulitan dalam hal matematika dianalisis lebih lanjut dengan dikaitkan pada dimensi kreatif dari Guilford, yaitu: fluency (kelancaran), flexibility (keluwesan),

Tabel 2.

Rubrik penskoran mathematical problem posing originality (keaslian), dan generalization (generalisasi). Rubrik penskoran untuk mengukur kemampuan mathematical problem posing siswa yang telah dikemukakan oleh Shriki (2013), disajikan pada tabel 2 berikut.

\begin{tabular}{ccc}
\multicolumn{3}{c}{ Tabel 2.} \\
& Rubrik penskoran mathematical problem posing & \\
\hline Indikator & Keterangan & Skor Relatif \\
\hline
\end{tabular}




\begin{tabular}{|c|c|c|}
\hline $\begin{array}{c}\text { Fluency } \\
\text { (kelancaran) }\end{array}$ & $\begin{array}{l}\text { Maksimum mathematical problem posing yang diajukan oleh siswa } \\
\text { sebanyak (misal } n \text { pertanyaan) mendapatkan skor maksimal yaitu } 100 . \\
\text { Siswa lain mengajukan mathematical problem posing sebanyak (misal } \\
m \text { pertanyaan). }\end{array}$ & $\frac{m}{n} \times 100$ \\
\hline $\begin{array}{c}\text { Flexibility } \\
\text { (keluwesan) }\end{array}$ & $\begin{array}{l}\text { Maksimum mathematical problem posing yang berbeda yang diajukan } \\
\text { oleh siswa sebanyak (misal } n \text { pertanyaan) mendapatkan skor maksimal } \\
\text { yaitu } 100 . \\
\text { Siswa lain mengajukan mathematical problem posing yang berbeda } \\
\text { sebanyak (misal } m \text { pertanyaan). }\end{array}$ & $\frac{m}{n} \times 100$ \\
\hline $\begin{array}{l}\text { Originality } \\
\text { (keaslian) }\end{array}$ & $\begin{array}{l}\text { Maksimum mathematical problem posing yang berbeda yang diajukan } \\
\text { oleh siswa kurang dari } \frac{1}{3} \text { dari seluruh siswa, sebanyak (misal } n \\
\text { pertanyaan) mendapatkan skor maksimal yaitu } 100 \text {. } \\
\text { Siswa lain mengajukan mathematical problem posing yang berbeda } \\
\text { sebanyak (misal } m \text { pertanyaan). } \\
\text { Siswa lain yang tidak mengajukan mathematical problem posing yang } \\
\text { berbeda mendapatkan skor } 0 \text {. }\end{array}$ & $\frac{m}{n} \times 100$ \\
\hline $\begin{array}{l}\text { Generalizati } \\
\text { on } \\
\text { (generalisasi) }\end{array}$ & $\begin{array}{l}\text { Maksimum mathematical problem posing yang tergolong masalah } \\
\text { generalisasi sebanyak (misal } n \text { pertanyaan) mendapatkan skor } \\
\text { maksimal yaitu } 100 . \\
\text { Siswa lain mengajukan mathematical problem posing yang memuat } \\
\text { generalisasi sebanyak (misal } m \text { pertanyaan). }\end{array}$ & $\frac{m}{n} \times 100$ \\
\hline
\end{tabular}

Sejalan dengan apa yang dilakukan oleh Shriki dalam rubric penskoran yang didasarkan pada dimensi kreatif, penelitian Chang dkk (dalam Sumarmo, 2014) pun menguraikan penskoran yang sejenis. Dikatakan sejenis dikarenakan rubric penskoran yang diajukan didasarkan oleh dimensi kreatif juga, hanya perbedaannya dalam pengambilan indikator kreatif yang digunakan dan aturan pemberian skor pada tiap bagian indikator itu sendiri. Berikut rubric penskoran yang dipaparkan oleh Chang disajikan pada tabel di bawah ini.

Tabel 3.

Rubrik penskoran berdimensi kreatif menurut Chang dkk (dalam Sumarmo, 2014)

\begin{tabular}{ll}
\hline \multicolumn{1}{c|}{ Dimensi Kreatif } & \multicolumn{1}{c}{ Kriteria } \\
\hline Ketepatan & $\begin{array}{l}\text { Dimensi ketepatan mathematical problem posing dinilai berdasarkan mathematical } \\
\text { problem posing yang diajukan. Tiap mathematical problem posing yang } \\
\text { benar/tepat diberi skor 0. }\end{array}$ \\
\hline Keluwesan & $\begin{array}{l}\text { Dimensi keluwesan mathematical problem posing dinilai berdasarkan banyaknya } \\
\text { ragam mathematical problem posing berbeda yang diajukan. Mathematical } \\
\text { problem posing yang memuat satu masalah berbeda diberi skor 1, dan } \\
\text { mathematical problem posing yang memuat lebih dari satu ragam masalah diniliai } \\
\text { lebih luwes dan diberi skor 2. Mathematical problem posing yang tidak } \\
\text { benar/tepat, dimensi keluwesannya tidak dinilai. }\end{array}$ \\
\hline Elaborasi & $\begin{array}{l}\text { Dimensi elaborasi mathematical problem posing dinilai dari banyaknya langkah } \\
\text { atau proses penyelesaian yang berbeda dalam mathematical problem posing yang } \\
\text { diajukan. Mathematical problem posing yang memuat satu langkah penyelesaian } \\
\text { diberi skor, dan yang lebih banyak memuat langkah penyelesian atau lebih } \\
\text { kompleks proses penyelesaian diberi skor 2. Mathematical problem posing yang } \\
\text { tidak benar/tepat, dimensi elaborasinya tidak dinilai. }\end{array}$ \\
\hline Keaslian & Keaslian mathematical problem posing dinilai dari banyaknya ragam mathematical \\
\hline
\end{tabular}


problem posing berbeda yang diajukan oleh sejumlah siswa. Bila suatu mathematical problem posing diajukan oleh lebih dari $5 \%$ dari seluruh siswa, maka mathematical problem posing tersebut diberi skor 1; bila mathematical problem posing diajukan oleh $2 \%-5 \%$ dari seluruh siswa, maka mathematical problem posing tersebut diberi skor 2, dan bila mathematical problem posing diajukan oleh kurang dari $2 \%$ dari seluruh mathematical problem posing maka mathematical problem posing tersebut diberi skor 3. Mathematical problem posing yang tidak benar/tepat dimensi keasliannya tidak dinilai.

Berbeda dengan apa yang dikemukakan empat komponen, yaitu: pemahaman oleh Rosli dkk (2013), mereka konsep, solusi dari masalah, kekreatifan mengemukakan rubrik penskoran yang masalah, dan solusi masalah dari teman. sedikit berbeda. Rosli dan teman- Berikut rubrik penskoran yang temannya memberikan penskoran melalui dikemukakan Rosli dkk (2013):

Tabel 4.

Rubrik Penskoran Mathematical Problem Posing menurut Rosli dkk

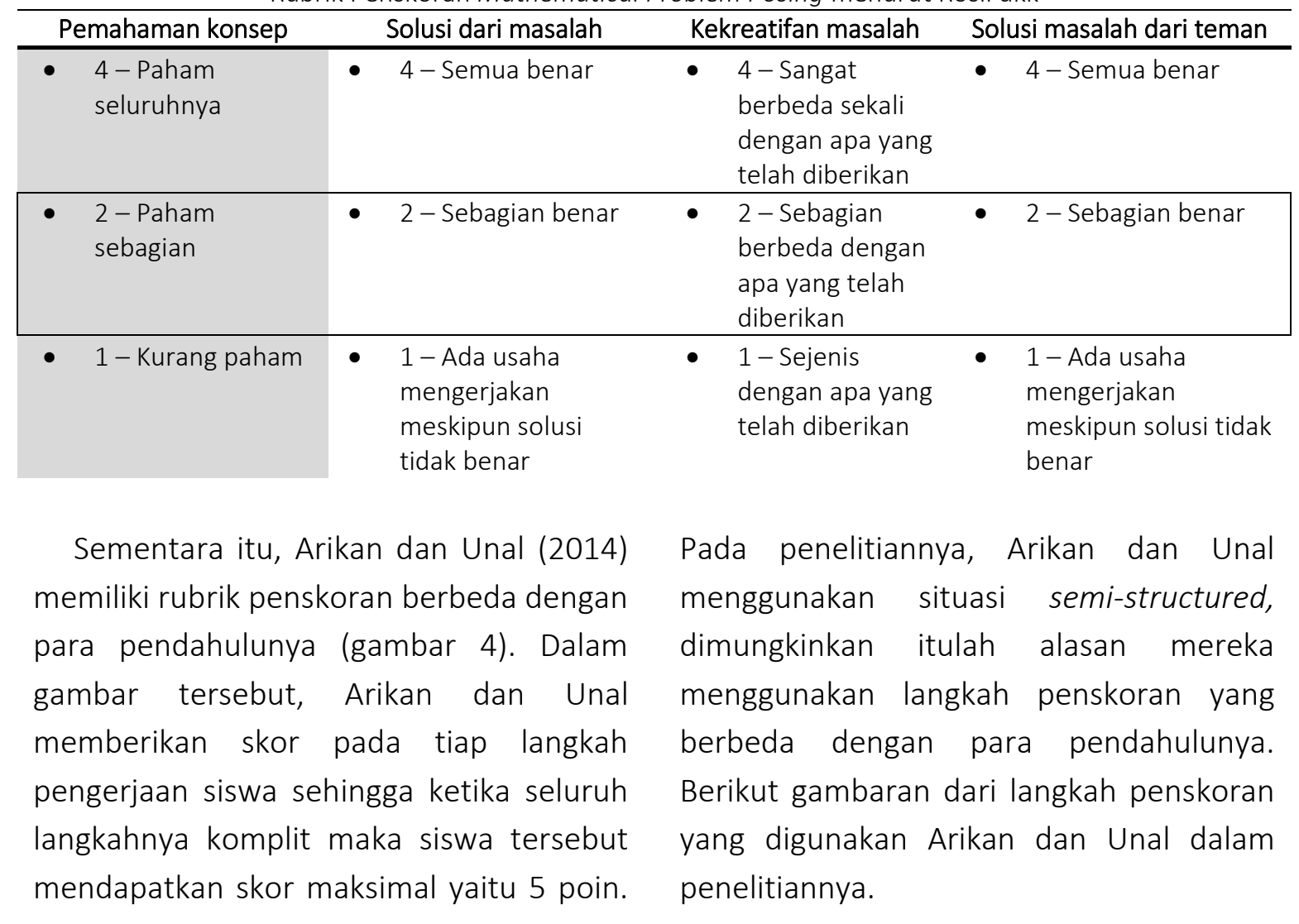




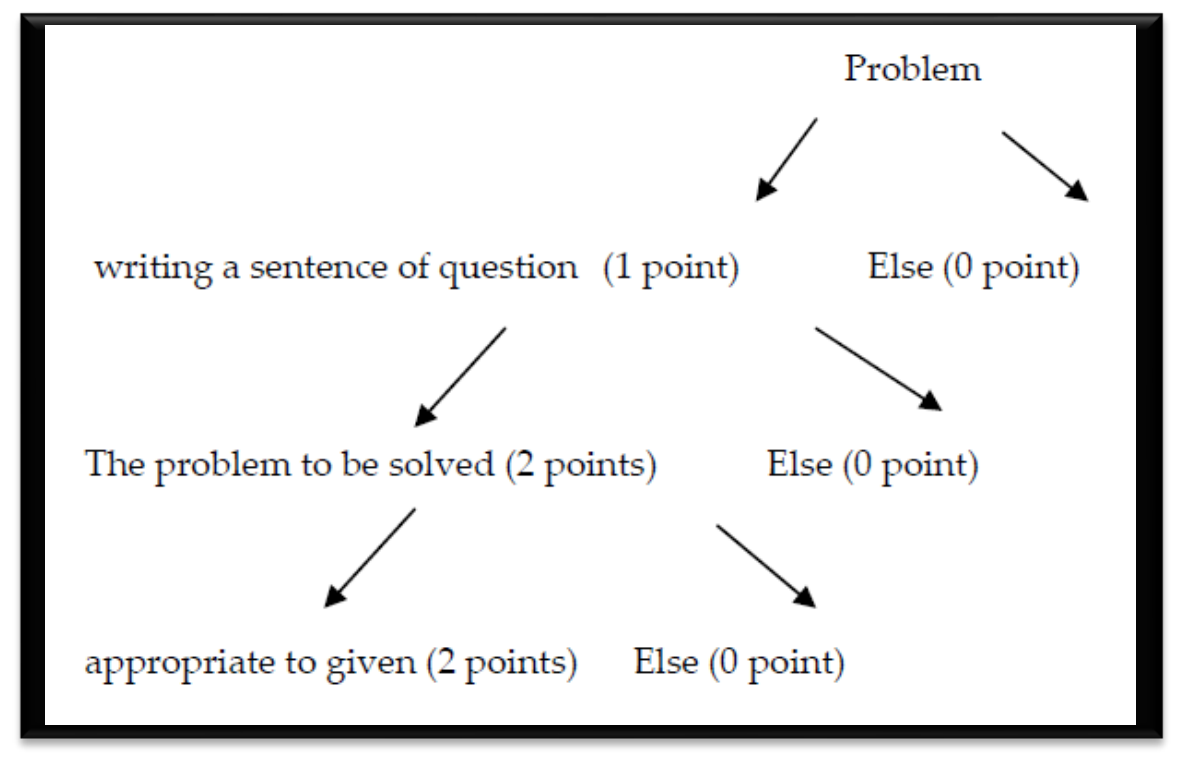

Gambar 4. Penskoran yang digunakan Arikan dan Unal (2014).

Stoyanova dan Ellerton (1996) memberikan contoh permasalahan untuk ketiga jenis situasi masalah problem posing yang mereka peroleh dari suatu kompetisi matematika, sebagai berikut:

1. Situasi masalah problem posing yang bebas:

Diberikan gambar situasi masalah berikut:

a. Buatlah sebanyak mungkin masalah matematik dari situasi di bawah ini.

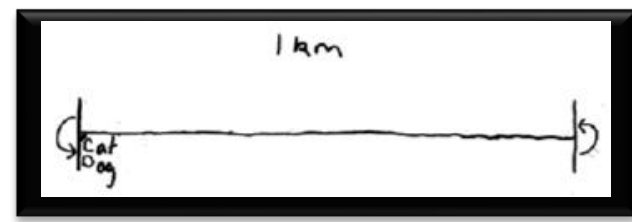

Gambar 5. Situasi Permasalahan.

b. Berikan contoh masalah matematik yang kamu sukai untuk kamu selesaikan. Berikan alasan mengapa kamu menyukainya dan bagaimana kamu membuat permasalahan itu. c. Buatlah masalah matematik yang menurut kamu sulit untuk kamu kerjakan.

2. Situasi masalah problem posing semiterstruktur:

a. Buatlah sebanyak mungkin masalah matematik dari sebuah penggunaan konsep rumus segitiga siku-siku.

b. Buatlah sebanyak mungkin masalah matematik yang penyelesaiannya nanti membutuhkan cara permutasi/kombinasi.

c. Buatlah sebanyak mungkin masalah matematik dengan menggunakan perhitungan sebagai berikut: $3 \times 25+$ $15+5-4$

3. Situasi masalah problem posing yang terstruktur:

Buatlah sebanyak mungkin masalah matematik dengan menggunakan situasi berikut: "Kemarin malam terdapat sebuah pesta dan saat itu bel berbunyi 10 kali. Bunyi bel pertama hanya satu orang yang 
hadir. Setelah itu, setiap kali bel berbunyi, tiga orang datang lebih banyak dari bunyi bel sebelumnya."

\section{Pembahasan}

Di awali dari penelitian Stoyanova dan Ellerton pada tahun 1996, keduanya membahas beberapa hal penting tentang problem posing. Salah satunya bagaimana guru menyajikan situasi masalah matematik yang sesuai untuk siswa. Stoyanova dan Ellerton (1996) mengatakan bahwa dalam mendesain masalah matematik ini, perlu diperhatikan tiga hal, sebagai berikut: (a) situasi problem posing sebaiknya berhubungan dengan aktivitas matematik siswa, (b) situasi problem posing dapat diperoleh dari buku teks dengan modifikasi dan perbaikan bahasa dan disesuaikan dengan karakteristik masalah yang diperlukan, dan (c) situasi problem posing sebaiknya merupakan bagian dari aktivitas problem solving siswa.

Kemudian pada tahun 1998, Cai melakukan penelitian tentang problem posing dengan mengambil sampel dari dua Negara yang berbeda, dengan maksud membandingkannya. Dalam penelitiannya, Cai mengambil sampel penelitian 181 siswa Amerika dan 223 siswa Cina di tingkat enam. Cai memaparkan dalam hasil penelitiannya bahwa secara keseluruhan kemampuan problem posing antara siswa Amerika dan siswa Cina berimbang. Akan tetapi, dalam masalah yang rumit, siswa Cina lebih unggul dibandingkan siswa Amerika. Selain itu, dalam penelitian ini,
Cai (1998) pun menemukan hubungan positif yang saling terkait antara kemampuan problem posing dan problem solving siswa Amerika maupun siswa Cina. Keterkaitan tersebut dapat dijadikan penelitian lanjutan yang sekiranya tertarik dalam kedua kemampuan tersebut.

Brown dan Walter (2005) menyatakan bahwa strategi "what if not" merupakan suatu cara yang relatif sederhana yang dapat mengangkat permasalahan baru dan memunculkan rasa ingin tahu siswa dalam proses pembelajaran. Perlu diketahui sebelumnya bahwa strategi "what if not" ini merupakan salah satu strategi dari problem posing. Strategi ini tentunya dapat memberikan kesempatan kepada siswa untuk menggunakan bentuk pemikiran yang fleksibel yang dikarakteristikkan sebagai cara berpikir dari seorang ahli matematik Weiss dan Moore-Russo (2012). Dalam penelitiannya, Weiss (2009) menganalisis sekumpulan dokumen naratif tentang penelitian ahliahli matematika yang mengungkap bahwa problem posing (bertanya permasalahan yang sulit dan 'fruitful' dari diri sendiri ataupun orang lain) berperan sama pentingnya dengan problem solving.

Brown dan Walter (2005) menerapkan problem posing dalam pendidikan matematika. Ketika seseorang menyadari "Dapatkah kita membuktikan ..." merupakan pertanyaan yang baik daripada "Bagaimana kita membuktikan ...", permasalahan yang 'intracable' menjadi 'tracable'. Pentingnya permasalahan yang diajukan oleh guru dalam pembelajaran, 
didukung juga oleh Crespo (2003) dalam penelitiannya. Crespo mengatakan di dalam penelitiannya bahwa perlunya meningkatkan dan menambah ide calon guru ketika memilih, mengadaptasi, dan posing permasalahan matematika terhadap siswa.

Beberapa penelitian dilakukan langsung terhadap para calon guru, seperti halnya Crespo (2003). Dalam penelitiannya mengkaji bagaimana para subjek calon guru diteliti dalam hal kemampuan problem posing di awal sebelum perlakuan seperti apa dan di akhir setelah perlakuan seperti apa. Di awal sebelum perlakuan, para calon guru cenderung melakukan problem posing dengan cara: (1) Membuat masalah yang mudah untuk diselesaikan, (2) Posing problem yang familiar di mata siswa, dan (3) Posing problem 'blindly' / tanpa persiapan/tanpa tujuan. Kemudian di akhir setelah perlakuan, terdapat perubahan pendekatan yang dilakukan oleh calon guru dalam melakukan problem posing, diantaranya: (1) Mencobakan permasalahan yang tidak familiar, (2) Posing permasalahan yang menantang siswa untuk berpikir, dan (3) Posing permasalahan untuk mempelajari apa yang dipikirkan oleh siswa.

Disini terungkap permasalahan tentang pertanyaan hubungan antara problem solving dan problem posing. Karena jika dilihat realitanya, ketika problem solving dengan mudahnya diidentifikasi sebagai aspek penting dalam belajar matematika, problem posing telah lama dilihat sebagai aspek yang terabaikan dalam matematika inquiry (Brown dan Walter, 1983). Didukung pula oleh Crespo (2003), ketika banyak perhatian telah difokuskan pada kemampuan kandidat guru untuk menyelesaikan permasalahan matematika, sedikit perhatian telah diberikan pada kemampuan mereka dalam membangun dan memberikan permasalahan matematika terhadap siswa nya. Sehingga dapat disimpulkan bahwa problem solver yang baik mungkin tidak selalu dapat memberikan 'pose' permasalahan matematika yang lebih baik daripada problem solver yang buruk.

Kali ini di dalam penelitian Shriki (2013), terdapat gambaran analisis yang dilakukan oleh Shriki dalam penelitiannya. Berikut gambaran ilustrasi dari analisis yang dilakukan oleh Shriki. 


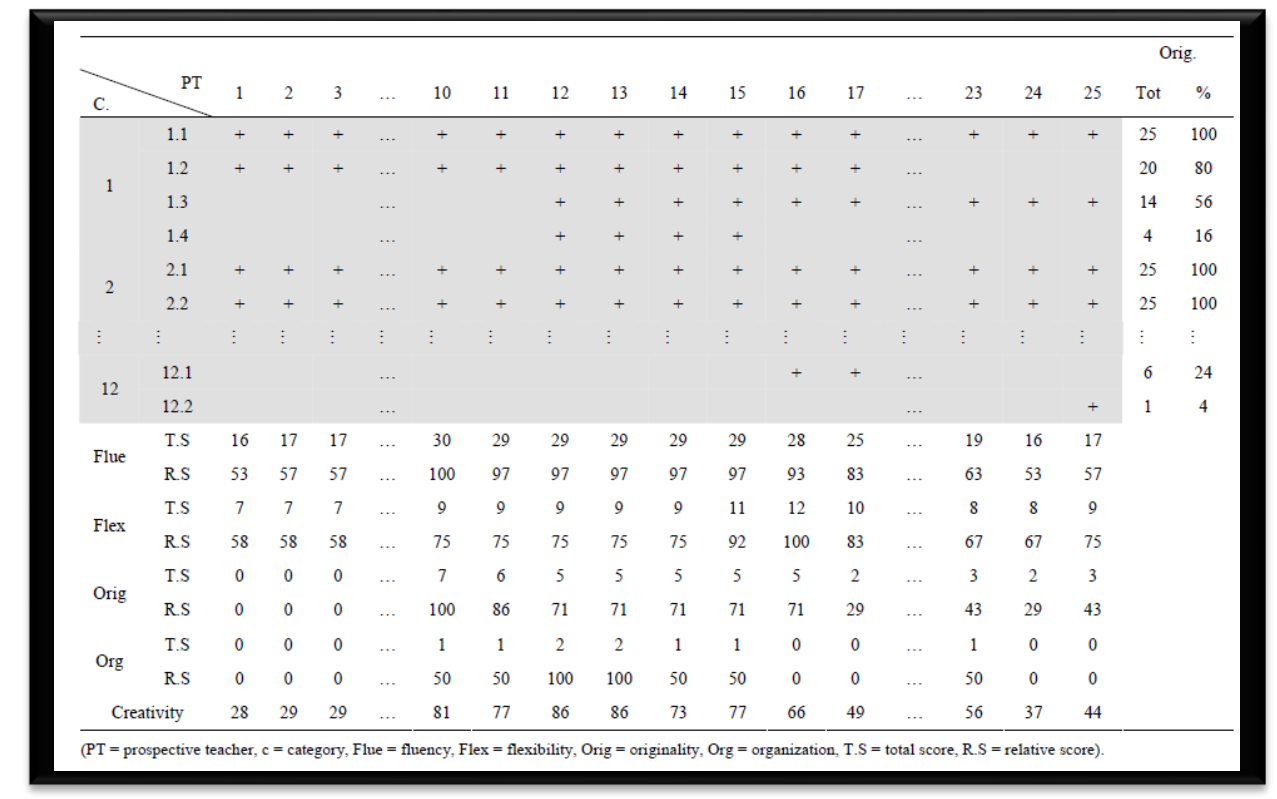

Gambar 6. Hasil analisis penskoran dalam penelitian Shriki (2013).

Dalam memahami gambar di atas, perlu diketahui bahwa dalam penelitiannya Shriki mengambil data sampel prospective teacher (PT) yaitu sebanyak 25 calon guru. Untuk pengajuan situasi permasalahannya, Shriki mengajukan 12 macam situasi. Shriki melakukan analisis penskoran ini dengan mengacu pada rubrik penskoran berdimensi kreatif yang Shriki telah kemukakan sebelumnya, bisa dilihat pada tabel 4.

Pada indikator kelancaran, dapat diperhatikan PT1 mengajukan masalah sebanyak 16 pertanyaan, sehingga total skor kelancarannya adalah 16 . Akan tetapi ketika dibandingkan dengan PT lainnya, perlu diperhatikan bahwa untuk indikator kelancaran ini yang mengajukan masalah terbanyak adalah PT10 sebanyak 30 pertanyaan, dan secara otomatis PT10 mendapat skor relative kelancaran sebesar 100. Sementara PT1 sesuai dengan perhitungan yang telah digambarkan pada rubric penskoran, skor relative kelancaran PT1 adalah [(16/30)*100]. Begitu pun PT lainnya dilakukan perhitungan yang sama.

Pada indikator keluwesan, dapat diperhatikan PT1 mengajukan masalah yang berbeda 7 pertanyaan dari 12 kategori pertanyaan yang ada, sehingga total skor keluwesannya adalah 7. Akan tetapi ketika dibandingkan dengan PT lainnya, perlu diperhatikan bahwa untuk indikator keluwesan ini yang mengajukan masalah yang berbeda terbanyak adalah PT16 sebanyak 12 pertanyaan, dan secara otomatis PT16 mendapat skor relative kelancaran sebesar 100. Sementara PT1 sesuai dengan perhitungan yang telah digambarkan pada rubric penskoran, skor relative kelancaran PT1 adalah $\left[(7 / 12)^{*} 100\right]$. Begitu pun PT lainnya dilakukan perhitungan yang sama.

Pada indikator keaslian, dapat diperhatikan PT10 mengajukan 7 masalah yang diajukan kurang dari 33\% dari PT 
lainnya sebanyak 7 pertanyaan, sehingga total skor keasliannya adalah 7 dan skor relative kesaliannya adalah 100 . Berbeda kasus dengan PT lainnya, sebagai contoh PT12, PT12 ini menyajikan 5 pertanyaan yang termasuk kategori pertanyaan yang diajukan kurang dari 33\% dari PT lainnya. Oleh karena itu, PT12 ini mendapatkan skor relative keasliannya sebesar [(5/7)*100]. Begitu pun PT lainnya dilakukan perhitungan yang sama.

Pada indikator generalisasi, dilihat secara keseluruhan untuk kategori mathematical problem posing yang termasuk indikator generalisasi ini hanya 5 permasalahan (1.4, 5.6, 5.10, 8.2, dan 9.2). Dapat diperhatikan untuk indikator ini, terdapat dua PT (PT12 dan PT13) yang mengemukakan masalah generalisasi terbanyak, yaitu 2 masalah generalisasi. Oleh karena itu, PT12 dan PT13 mendapatkan skor total generalisasi sebesar 2 dan skor relatif generalisasi sebesar 100. Sementara itu, untuk PT yang hanya mengajukan masalah generalisasi sebanyak 1 pertanyaan mendapatkan skor total generalisasi 1 dan skor relatif generalisasi 50. Sisanya yang tidak mengajukan soal generalisasi mendapatkan skor 0 .

Selain dari ilustrasi analisis penskoran, peneliti mendapatkan hal menarik dari penelitian Shriki (2013), yaitu dalam hal pengambilan keputusan Shriki tentang alasan mengapa dalam rubruk penskoran yang Shriki ajukan pada indikator keasliannya diambil persentase 33\%. Shriki berpedoman pada penelitian Leikin dkk
(2009), pada penelitian Leikin dkk diteliti kemampuan mathematical problem posing siswa dimana penskoran untuk indikator keaslian diklasifikasikan dalam 3 kategori, yaitu: (1) mathematical problem posing yang diajukan siswa kurang dari 15\% siswa secara keseluruhan, (2) mathematical problem posing yang diajukan siswa antara $15 \%$ sampai $40 \%$ dari siswa secara keseluruhan, dan (3) mathematical problem posing yang diajukan siswa lebih dari 40\% siswa secara keseluruhan. Berdasarkan penelitian tersebut, didukung dengan observasi yang dilakukan pada proposed teacher (calon guru), Shriki mengambil persentase keputusan bahwa mathematical problem posing yang dikatakan asli pada penelitiannya adalah mathematical problem posing yang diajukan siswa kurang dari 33\% siswa secara keseluruhan.

Kilic (2013) mencari tahu opini dari guru-guru SD di Turki tentang aplikasi problem posing pada siswa, kurikulum, dan buku teks. Dalam penelitiannya, Kilic mengambil sampel penelitian sebanyak 277 guru SD yang tersebar ke dalam 18 sekolah. Tia guru diberikan kuesioner berisikan pertanyaan yang berkaitan dengan problem posing dan kaitannya dengan siswa, kurikulum, dan buku sekolah dengan total pertanyaan sebanyak 30 buah. Hasilnya terdapat pandangan positif terhadap kaitan antara aplikasi problem posing ini dengan siswa. Sementara opini negative diperoleh untuk kaitan dari problem posing dengan kurikulum dan buku teks. Beberapa hal 
yang menjadi kendala sehingga menimbulkan opini negative ini perlu dicari solusinya sebagai saran untuk penelitian lanjutan. Disamping hasil dari penelitian yang diperoleh, Kilic mengemukakan bahwa opini positif diperoleh pada kaitan antara problem posing dan siswa dikarenakan problem posing ini sangat penting untuk dikuasai siswa. Melalui kemampuan mathematical problem posing ini, siswa dapat memperoleh pemahaman konsep dan keterampilan yang baik ketika dihadapkan suatu masalah matematik; guru pun dapat dengan mudah melakukan evaluasi sesuai dengan kemampuan mathematical problem posing yang dimiliki siswa.

\section{Penutup}

Berdasarkan penjelasan dari berbagai penelitian yang telah dilakukan, dapat kita simpulkan pentingnya kemampuan ini untuk dimiliki oleh seorang guru. Oleh karena itu, ada baiknya untuk institusi yang mendidik calon guru agar memperhatikan hal ini, sehingga guru tidak hanya pandai dalam menyelesaikan suatu permasalahan matematis tetapi juga pandai dalam membuat permasalahan dengan berbagai situasi/tingkatan sesuai dengan apa yang dibutuhkan siswanya.

\section{Daftar Pustaka}

Arikan, E. A. \& Unal, H. (2014). Development of the structured problem posing skills and using metaphoric perceptions. European Journal of Science and Mathematics
Education Vol. 2, No. 3, 2014, 155166.

Bonotto, C. (2013). Artifacts as sources for problem-posing activities. Educational Studies in Mathematics (2013) 83: 3755. DOI 10.1007/s10649-012-9441-7

Brown, S. I. dan Walter, M. I. (1983). The Art of Problem Possing. Lawrence Erlbaum Associates. Hillsdale. New Jersey.

Brown, S. I. dan Walter, M. I. (2005). The Art of Problem Posing, $3^{\text {rd }}$ ed. Mahwah, New Jersey: Lawrence Erlbaum Associattes, Inc.

Cai, J. (1998). An Investigation of U.S. and Chinese Students' Mathematical Problem Posing and Problem Solving. Mathematics Education Research Journal Vol. 10, No. 1, 37-50.

Choe, Y. and Mann, A. (2012). From Problem Solving to Problem Posing. Brain-Mind Magazine, Vol. 1, No. 1, Hal. 7-8.

Crespo, S. (2003). Learning to pose mathematical problems: Exploring changes in preservice teachers' practices. Educational Studies in Mathematics 52: 243-270. Kluwer Academic Publishers. Netherlands.

Da Ponte, J.P and Henriques, A. (2013). Problem Posing Based on Investigation Activities by University Students. Educational Studies in Mathematics 83:145-156.

Ellerton, N.F and Clarkson, P.C. (1996). Language factors in mathematics teaching and learning. International 
handbook of mathematics education.

Springer Netherlands: 983-1033.

Kilic, C. (2013). Turkish Primary School Teachers' Opinion about Problem Posing Applications: Students, the Mathematics Curriculum and Mathematics Textbooks. Australian Journal of Teacher Education Vol. 38 Issue 5. 144-155.

National Council of Teachers of Mathematics (NCTM). (1991). Profesional Standards for Teaching Mathematics, NCTM, Reston, VA.

NCTM, (2000). Principles and Standars for School Mathematics. Tersedia: http://www.nctm.org/standards/cont ent.aspx?id=16909

Polya, G. (1985). How to Solve it: A New Aspect of Mathematics Methods. $\left(2^{\text {nd }}\right.$ ed.). Princeton, New Jersey: Princeton University Press.

Rosli, R., Goldsby, D., \& Capraro, M. M. (2013). Assessing Students' Mathematical Problem-Solving and Problem-Posing Skills. Published by Canadian Center of Science and Education. Asian Social Science; Vol. 9, No. 16: $2013 . \quad$ 54-60. Doi:10.5539/ass.v9n16p54

Shiriki, A. (2013). A Model for Assessing the Development of Students Creativity in the context of ProblemPosing. Creative Education, Vol.4, No.7, 430-439, 2013.

Silver, E. A. \& Cai, J. (1996). An analysis of arithmetic problem posing by middle school students. Journal for Research in Mathematics Education, Vol. 27(5), pp.521-539.

Silver, E. (1994). On Mathematical Problem Posing. For the Learning if Mathematics 14(1): 19-28.

Stoyanova, E. \& Ellerton, N. F. (1996). A Framework for Research into Students' Problem Posing in School Mathematics. Edith Cowan University. 518-525.

Sumarmo, U. (2014). Mathematical Problem Posing: Pengertian, Rasional, Pengembangan Pembelajaran dan Pengukurannya. Modul Pembelajaran Kuliah S3 Pendidikan Matematika. Bandung: Pascasarjana UPI.

Weiss, M. (2009). Mathematical Sense, Mathematical Sensibility: The Role of the Secondary Geometry Course in Teaching Students to be Like Mathematicians. PhD diss, University of Michigan.

Weiss, M. K. dan Moore-Russo, D. (2012). Thinking Like a Mathematician. The Mathematics Teacher, Vol. 106, No. 4, Hal 269-273. Published by National Council of Teachers of Mathematics.

\section{Riwayat Hidup PenUlis Ekasatya Aldila Afriansyah, M.Sc.}

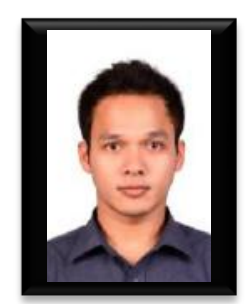

Lahir di Bandung, 4 April 1986. Dosen Tetap Yayasan STKIP Garut. Studi S1 Matematika Konsentrasi Statistika UPI, Bandung, lulus tahun 2009; S2 Pendidikan Matematika UNSRIUTRECHT, PalembangUtrecht, lulus tahun 2012; dan S3 Pendidikan Matematika UPI, Bandung, sampai sekarang 
This page is intentionally left blank 